\title{
SOME APPROACHES TO OBTAINING INTERNAL AUDIT EVIDENCE FOR PHARMACEUTICAL QUALITY SYSTEMS
}

\author{
T. Karamavrova, V. Lebedynets
}

\begin{abstract}
Метою роботи є аналіз підходів та розробка пропозицій щзодо вибору оптимальних методів збору свідочтв внутрішніх аудитів фармацевтичних систем якості.

Матеріали та методи. Базою для дослідження були матеріали чинної державної законодавчої й нормативної бази, стандарти ISO серії 9000, джерела зарубіжної й вітчизняної наукової фахової літератури, а також результати власних попередніх досліджень. У дослідженні використано наступні методи: системно-аналітичний, сочіологічного опитування, порівняльного аналізу, структурно-логічного моделювання.
\end{abstract}

Результати. За результатами попередніх досліджень, щзо проводились на базі вітчизняних фармацевтичних підприсмств різного профілю діяльності, було встановлено, щуо основна причина часто недостатньої ефективності внутрішніх аудитів полягає у низькому рівні професіоналізму аудиторів. На даному етапі дослідження було проведено вивчення такого методу внутрішніх аудитів, як опитування, а також проаналізовано підходи до його застосування. Зокрема, з'ясовано, що метод опитування на вітчизняних фармацевтичних підпиємствах використовують як основний метод збору свідоцтв аудиту для їх подальшого оцінювання й інтерпретації. Також було доведено, щзо одне з ключових умінь аудитора - ставити коректні, дочільні запитання для отримання інформативних відповідей. Було розроблено та апробовано алгоритм постановки аудиторських запитань, оптимізований для збільщення повноти й змістовності відповідей персоналу.

Висновки. Дослідження дозволило запропонувати техніку опитування, ефективну для збору аудиторських свідоцтв, щзо підвищує результативність процесу внутрішніх аудитів завдяки збільшенню ијіності здобутої інформації з позииії прийняття управлінських рімень

Ключові слова: система управління якістю, фармацевтична система якості, самоінспекція, внутрішній аудит, фармацевтична діяльність, GMP, ISO 9001

Copyright (C) 2019, T. Karamavrova, V. Lebedynets This is an open access article under the CC BY license (http://creativecommons.org/licenses/by/4.0).

\section{Introduction}

Quality management system (QMS) of pharmaceutical companies of the healthcare industry (pharmaceutical quality systems, PQS), which are engaged in pharmaceutical development, production and marketing of medicinal substances (active pharmaceutical ingredients, API) and medical product (MP), should be systematically evaluated by competent auditors for compliance with all requirements established for such systems and making recommendations for improvement $[1,2]$. These requirements emphasize the link between the results of the self-inspection (internal audits, IA)-with the corrective and preventive actions required for continuous improvement of the PQS [3, 4]. Normative documents described as a whole the process of performing the IA, but they don't regulate the use of specific audit methods and do not provide the specific approaches to evaluating and analyz-ing audit results.

In order to assess the state of organization of the IA process at domestic pharmaceutical companies (PC), we conducted a sociological survey among 79 manufacturing and wholesale drug companies, the results of which showed that most PC in Ukraine have problems regarding various aspects of IA, in particu- lar, due to the competence of the auditors, the use of different audit methods, the interpretation of audit evidence, etc. [5].

The main reason for the low IA effectiveness is found to be the lack of professionalism of the auditors, which is reflected in, for example, the lack of a constant ability to conduct interviews, analytical monitoring of staff work, proper audit evaluation and interpretation of different work situations. Poll-related issues include the focus of such an effective audit method only on finding non-compliance with specific regulatory requirements, but not on determining the functioning of the individual process and QMS as a whole. Often, when auditors conducting the interviews, the questions are a formal nature and are closed-ended. In addition, auditors ask questions not only about the audit object identified in the plan, but also about other activities performed in the unit. At the same time, it is known that not focusing IA on the functioning of the QMS processes, but rather on the activities of the units complicates and slows down the audit procedure and increases the risks of failure to achieve the audit objectives $[5,6]$.

Issues of organization and improvement of the internal audit process have been investigated by scholars in various fields. In particular, previous studies have consid- 
ered issues of conducting IA in clinical diagnostic laboratories [7], issues of increasing the effectiveness of IA in the chemical industry [8], approaches to the organization of IA in the quality control system of medical care [9].

Pharmaceutical specialists have also investigated the relevant issues. In particular, the importance of IA for the proper functioning of PQS is substantiated, an analysis of common approaches to conducting IA is provided [10]. To improve the audit process was recommended to implementing a risk-based approach. The authors argue that applying this approach can provide a more systematic evaluation of activities [11]. In addition, the issue of audits of integrated management systems for PC has been investigated [12]. The questionnaire survey method was presented as a tool for conducting audits of pharmaceuticals distribution companies [13]. At the same time, there are publications with the opposite opinion of experts, who believe that this approach does not allow evaluating the QMS of PC in full because of the possible discrepancy in the questionnaire with the actual state of QMS functioning.

The problem of classifying questions in jurisprudence has been studied to address the issue of improving the effectiveness of communication [14]. In our opinion, the concepts of communication (questioning, dialogue, and interview) in the process of litigation and auditing are similar, so the results of these studies can be successfully used in conducting IA PQS.

However, we haven't find research findings on issues related to the use of audit methods in general and the interview method in particular.

Thus, the results of the review of the literature and our own studies conclude that the question of optimizing the use of the survey method in conducting IA is relevant in general, and for PC in particular [5, 6]. Based on this, the purpose of the study was to analyze approaches and develop suggestions for interviewing the staff during conducting IA to collect the evidence needed to make objective, impartial audit decisions.

\section{Planning (methodology) of the research}

At the beginning of the study, it was necessary to study the issues and outline the objects that are relevant to the aim of the study. According to the results of the analytical review of professional literature, normative and legislative requirements $[15,16]$, as well as earlier researches in the indicated direction, empirical research methods were chosen to achieve this goal.

We have developed the following research plan:

- study the issues of the application of audit methods;

- analysis of the relevant legal framework and professional literature, which presents the results of studies on the subject;

- development of proposals for drawing up the optimal format and algorithm for conducting the audit an interview to obtain the audit evidence;

- determination of perspectives of the practical application of the obtained results and directions of further research on the topic.

\section{Materials and methods}

The basis for the study were sources of scientific literature of foreign and domestic scientists, ISO 9000 standards, the regulatory framework of the pharmaceutical field of health care related to the functioning of PQS, as well as the results of own studies on the analysis of the IA process on PC. The methods of empirical research were used in the work: systematic-analytical, sociological questioning, comparative analysis, structural-logical modeling.

\section{Results and discussion}

Most often, the following methods are used when conducting audits [15]:

- analyzing of documented information;

- interviewing employees at the audited entity;

- observing the activities of the staff at the audited entity.

In the table. 1 provides a brief description of IA methods. It is worth noting that the integrated application of these methods usually allows the audit to be performed more efficiently by obtaining more useful information about the state of operation of the audited entity.

Table 1

Description of the use of methods of internal audit

\begin{tabular}{|l|l|}
\hline \multicolumn{1}{|c|}{$\begin{array}{c}\text { Methods of } \\
\text { internal audit }\end{array}$} & \multicolumn{1}{c|}{ Description of methods } \\
\hline $\begin{array}{l}\text { Analysis of doc- } \\
\text { umented infor- } \\
\text { mation }\end{array}$ & $\begin{array}{l}\text { The documented QMS requirements are verified, namely: the state of compliance of the activities } \\
\text { of the audited entity with the established normative and internal requirements, as well as compari- } \\
\text { son of planned indicators and actual results of the activity. }\end{array}$ \\
\hline $\begin{array}{l}\text { Conducting inter- } \\
\text { views }\end{array}$ & $\begin{array}{l}\text { It is used to obtain primary information about the audit object in the form of answers to questions. } \\
\text { The interview can be conducted in the form of a questionnaire survey (via a written question- } \\
\text { naire) or in the form of a direct interview with employees of the audited entity. }\end{array}$ \\
\hline Observation & $\begin{array}{l}\text { It is used to collect verifiable facts that are used to ensure the auditor's judgment is objective. } \\
\text { Observations are based on familiarity with the activities of the audit entity, the situation over- } \\
\text { view, the study of operations and procedures performed, the behavior of staff in the workplace, } \\
\text { the conditions of the working environment, the state of infrastructure, etc. }\end{array}$ \\
\hline
\end{tabular}

The registration of the results of the application of the above audit methods involves the detection, identifi- cation, classification of situations by their importance, as well as the logging of information. 
Interviewing is the most applicable audit method that, unfortunately, is not given proper attention. Based on the results of our research, we find that it is advisable to conduct the interview at certain stages. The proposed poll algorithm is presented in the form of a diagram in Fig. 1.
In the first stage (Fig. 1, item 1), the parties of the audit agree on organizational issues, the auditors announce the purpose, conditions and format of the audit. This stage also includes a preliminary meeting where representatives of the process under review should be present.

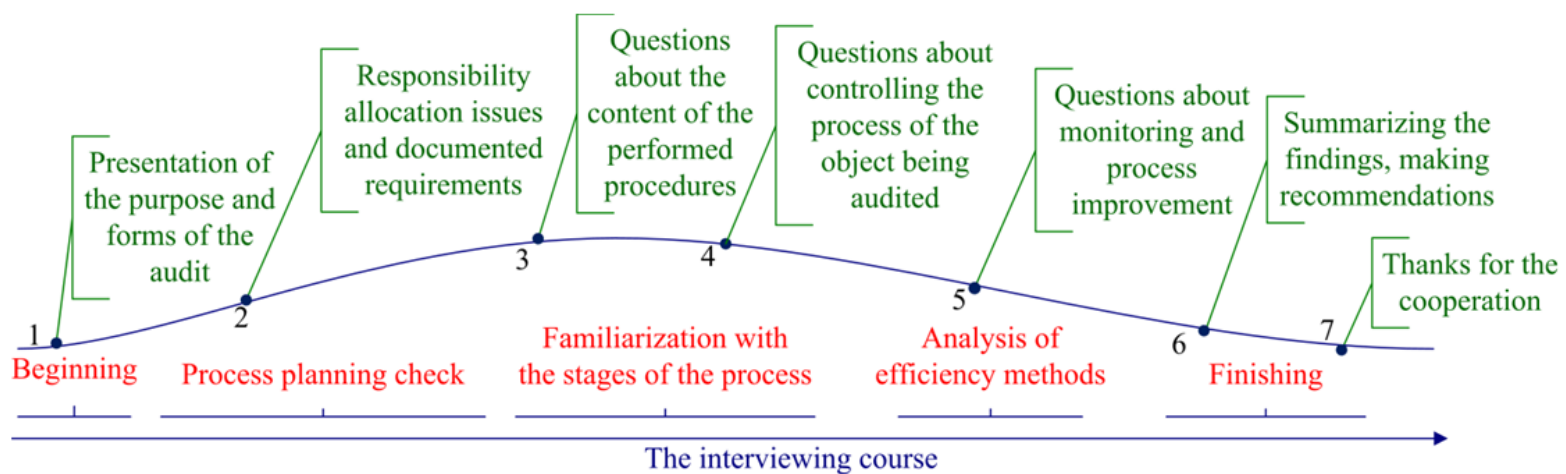

Fig. 1. The algorithm for conducting internal audit interviews

The following steps relate directly to the on-site audit: reviewing process of planning activities, reviewing the process stages and results of analyzing and evaluating work on the audit entity, reviewing the results of the improvement of implemented activities. For this reason, the subject matter and procedure for conducting the interview should be provided in advance to the audited party for better organization of working time. It is good practice to conduct interviews at the workplace of employees and not in a specially designated room for auditors, so that auditors are given the opportunity to monitor activity in parallel and to analyze work documents.

It should be noted that conducting a productive interviews involves a certain order of the questions. The process-oriented questions allow you to trace the actual implementation of the PDCA methodology within each audited process. During such an audit, it is possible to evaluate the implementation of all phases of the PDCA cycle - from planning to taking action to improve the process [6].

At the stage of auditing the planning process (Fig. 1, item 2), it is advisable to address the process manager with a question. The questions should relate to the distribution of responsibilities and powers among the contractors, maintaining the required level of professional training, awareness of the documented procedures, availability of necessary resources and other aspects.

It is known that any questions of the auditors can have a psychological impact on the interlocutor, so the auditor should be tactful and ask questions of a neutral nature $[6,14]$. Audit evidences are considered to be objective only if they are supported by the relevant facts. Otherwise, such evidence is subjective and therefore cannot be used by the auditor to make a decision and report [6].

It is proved that during the audit it is necessary to use the question-request form: "Could you (show, demonstrate, explain, justify)...., please?". In this case, the interlocutor will not feel pressure from the auditor, and the format of the audit will be open and friendly [14]
We offer a classification of questions that can be used during IA QMS. Therefore, by its focus, the questions can be divided into:

- main - used to find out the subject of communication; focus on specific audit topics;

- additional - used to detail the interlocutor's answer when the answers to the basic questions are too short.

In turn, it is suggested to divide the additional questions into:

- reminders (help to flesh out the answer),

- clarification (help to disseminate information about the subject of the interview),

- control (used to confirm the collected facts).

Control questions are often revealing when auditors identify differences between actual actions and the documented requirements of an audited entity. It is also a good practice to use detailed questions to confirm the collected data and sources of information [14]. The scheme of classification of audit questions is shown in Fig. 2.

The choice of one type of question depends on the specific purpose of the interview and the situation in which it is conducted. In most cases, it is advisable to ask questions that will be answered and provided with explanations (open-ended questions). Questions that require short yes or no answers (closed) are often uninformative, especially during internal audits.

Choosing the right question formulation is crucial to achieving the goal of the interview. In the Table 2 there are examples of the formulation of questions constructed according to the above classification. The following questions are of a system level and should be used during the audit to reveal the functioning status of each QMS process. With this approach, the results of the audits will testify to the state of organization of each process, which will allow to identify "system errors" in the activity of the enterprise, and not only to focus on the shortcomings in the work of individual contractors [6]. 


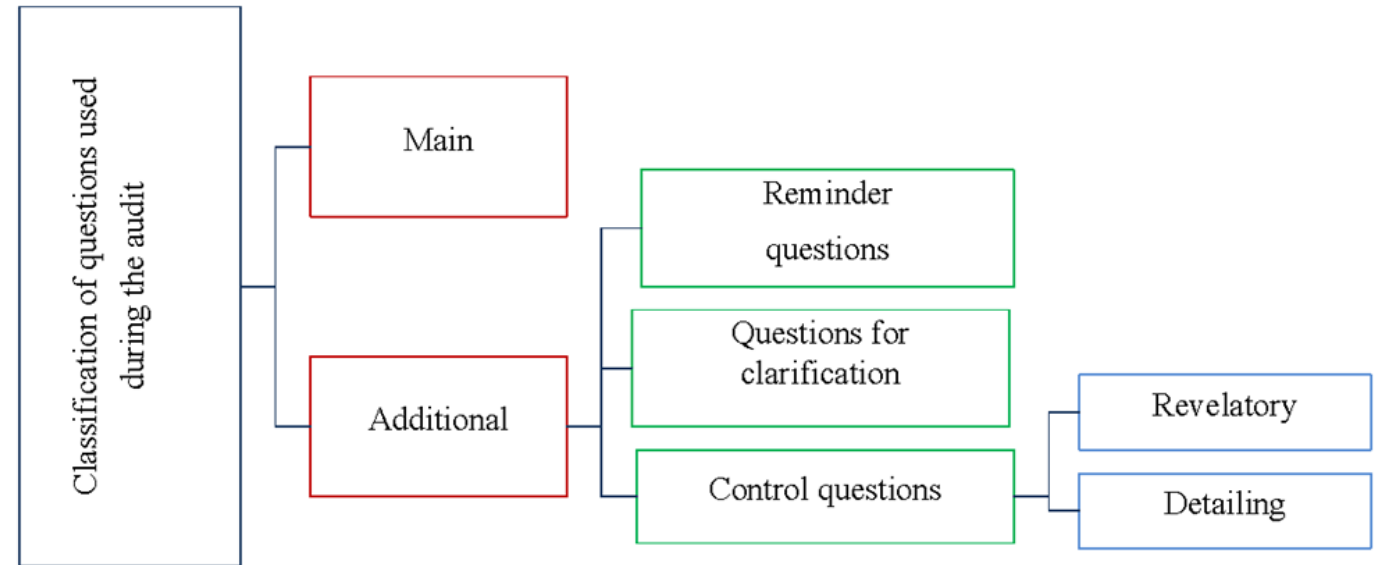

Fig. 2. Classification of questions used during the audit

Table 2

Types and examples of audit questions

\begin{tabular}{|c|c|c|c|}
\hline \multirow{2}{*}{$\begin{array}{l}\text { No. in } \\
\text { Fig. } 1\end{array}$} & \multirow{2}{*}{ Audit stage } & \multicolumn{2}{|c|}{ Types of questions } \\
\hline & & Main & Additional \\
\hline 2 & $\begin{array}{l}\text { Responsibility } \\
\text { allocation issues } \\
\text { and documented } \\
\text { requirements }\end{array}$ & $\begin{array}{l}\text { Describe the algorithm of the process (pro- } \\
\text { cedure). } \\
\text { Name the responsible executors of the pro- } \\
\text { cess (procedure). } \\
\text { How are responsibilities shared between } \\
\text { process performers? } \\
\text { How is the resources of the process provided? } \\
\text { How are the results of the improvement } \\
\text { activities checked? }\end{array}$ & $\begin{array}{l}\text { How is the process initiated? From which } \\
\text { other QMS processes does the data come } \\
\text { for this process? } \\
\text { How are process delegates informed } \\
\text { about the distribution of responsibilities, } \\
\text { changes in this allocation? How is staff } \\
\text { aware of their quality policies and objec- } \\
\text { tives, as well as their specific objectives? }\end{array}$ \\
\hline 3 & $\begin{array}{l}\text { Questions about } \\
\text { the content of the } \\
\text { performed pro- } \\
\text { cedures }\end{array}$ & $\begin{array}{l}\text { What documentation contains requirements } \\
\text { for this operation / process? } \\
\text { How does it usually happen ... operation / } \\
\text { process? }\end{array}$ & $\begin{array}{l}\text { In which documents are the results of the } \\
\text { procedure recorded? Please provide ex- } \\
\text { amples of recent ... changes / days / } \\
\text { months. Where and how is the data col- } \\
\text { lected transferred? Where and how much } \\
\text { are stored? How is feedback organized? }\end{array}$ \\
\hline 4 & $\begin{array}{l}\text { Questions about } \\
\text { controlling the } \\
\text { process of the } \\
\text { object being } \\
\text { audited }\end{array}$ & $\begin{array}{l}\text { By whom and how is each stage of the } \\
\text { process controlled? By what indicators and } \\
\text { criteria? By what methods? Where and how } \\
\text { are the results of inspections recorded? } \\
\text { How do they determine the degree to which } \\
\text { the process outcome requirements are met? }\end{array}$ & $\begin{array}{l}\text { How are deviations / inconsistencies } \\
\text { recorded during the process? How are the } \\
\text { results of process changes introduced and } \\
\text { controlled? Where and how are data } \\
\text { recorded on the functioning of the pro- } \\
\text { cess, its effectiveness? How is the man- } \\
\text { agement informed about the status of the } \\
\text { process / resource requirements / rejec- } \\
\text { tion and non-conformities / reform pro- } \\
\text { posals, etc.? }\end{array}$ \\
\hline 5 & $\begin{array}{l}\text { Questions about } \\
\text { monitoring and } \\
\text { process im- } \\
\text { provement }\end{array}$ & $\begin{array}{l}\text { How are cases of deviations and / or dis- } \\
\text { crepancies investigated; how are causation } \\
\text { relationships established? How are root } \\
\text { causes of problematic situations identified? } \\
\text { How is risk assessment and control per- } \\
\text { formed? Who and how are corrective and } \\
\text { preventative actions developed? How is } \\
\text { such action monitored? How is their per- } \\
\text { formance evaluated? }\end{array}$ & $\begin{array}{l}\text { How is process performance improved? } \\
\text { How are the results of the measures taken } \\
\text { monitored and evaluated? What actions } \\
\text { and facts indicate a reduction in quality } \\
\text { risks? How do you make sure staff are } \\
\text { aware of the need to constantly improve } \\
\text { their activities, and how do they care? }\end{array}$ \\
\hline
\end{tabular}

An important condition for a proper audit is to record all the answers to the auditor's questions during the interview and not at its end [6]. Forming audit teams of 2-3 auditors is a good practice to ensure that all important information is recorded.
At the end of the audit, a final meeting is held (Fig. 2, item 6-7), within which the results are summarized and recommendations made to improve the process. In order to approve the proposed methodology, we conducted a survey among domestic PC employees who 
perform the functions of internal auditors. Respondents were provided with briefing material, which included theoretical material, on-site audit techniques, and a checklist with examples of key questions.

After testing the methodology, the 11 respondents were asked to evaluate it by selecting certain statements (Fig. 3). The results of the survey showed the practical usefulness of the proposed methodology: approximately $78 \%$ of respondents noted significant time savings in the preparation and conduct of audits. Respondents also noted that the methodology made it possible to specify the subject of the audit and to expand the amount and content of information recorded during the audit $(81 \%)$. Approximately $63 \%$ of respondents said that preparing detailed checklists takes a considerable amount of time, while at the same time allowing auditors to be significantly better prepared, which has a positive impact on audit results.

\section{QUESTIONNAIRE}

for analysis of satisfaction with the proposed method of conducting internal audits of quality management system at pharmaceutical companies

Any information you provide in the questionnaire will not be published with your company name! Surveys are conducted for statistical analysis

Your company name:

Your position:

\section{Instructions for filling out a list:}

The statements only provide one estimate: "Yes" or "No". You must put the cross under the appropriate mark on one line with the selected statement.

\begin{tabular}{|c|c|c|c|}
\hline № & \multicolumn{1}{|c|}{ List of statements } & YES & NO \\
\hline 1 & Did the proposed audit methodology help in : & & \\
\hline 1.1 & - saving time & & \\
\hline 1.2 & - increase the content of audit evidence & & \\
\hline 1.3 & - increasing the organization of the audit process & \\
\hline 1.4 & $\begin{array}{l}\text { - increased willingness to cooperate with auditors and employees of } \\
\text { audited entity }\end{array}$ & \\
\hline
\end{tabular}

Fig. 3. Fragment of the questionnaire used in the study

\section{Conclusions}

It is argued that the interview, as a key method of conducting QMS audits, are an important tool for collecting and interpreting audit certificates. In addition, conducting the interview requires careful preparation of appropriate documentation and auditors' competence regarding the audit process and criteria.

Preparation of checklists with questions on the proposed sequence gives an opportunity to optimize the process of obtaining testimonials and audit certificates with their registration for further processing and making an objective audit decision.

During the IA, the proposed algorithm gives rise to a thorough review of the state of operation of the audit entity that is recommended to determine the QMS process. This approach allows us to establish the facts of systemic violations / deviations / inconsistencies, rather than focusing only on the errors of specific performers. It also makes it easier to see the differences between the actual execution of the work and the documented procedures.

It is proven that following the recommendations in practice saves time for preparing and conducting audits; specify the subject matter of the audit and expand the amount and content of the information recorded during the audit; it is better to prepare the auditors and obtain more useful audit results.

In the future, we plan to develop a set of applied recommendations for the organization of audit activities on $\mathrm{PC}$.

\section{Conflict of interests}

There are no conflicts of interest regarding this study.

\section{References}

1. Pro zatverdzhennia Litsenziinykh umov provadzhennia hospodarskoi diialnosti z vyrobnytstva likarskykh zasobiv, optovoi ta rozdribnoi torhivli likarskymy zasobamy, importu likarskykh zasobiv (krim aktyvnykh farmatsevtychnykh inhrediientiv): Postanova KMU No. 929. 30.11.2016. Available at: https:/www.kmu.gov.ua/ua/npas/249579316 Last accessed: 06.06.2018

2. EudraLex - Volume 4 Good manufacturing practice (GMP) Guidelines. Available at: https://ec.europa.eu/ health/documents/eudralex/vol-4 en

3. ICH guideline Q10 Pharmaceutical Quality System. 2015. EMA/CHMP/ICH/214732/2007. Available at: https://ec.europa.eu/health/documents/eudralex/vol-4_en

4. Likarski zasoby. Nalezhna vyrobnycha praktyka: ST-N MOZU 42-4.0:2015 (2015). Kyiv: MOZ Ukrainy, 336.

5. Lebedynets, V. O., Karamavrova, T. V. (2017). Analiz funktsionuvannia protsesu vnutrishnoho audytu na vitchyznianykh farmatsevtychnykh pidpryiemstvakh. Sotsialna farmatsiia v okhoroni zdorovia, 3 (3), 58-65. 
6. Kotvitska, A. A., Lebedynets, V. O. (2015). Orhanizatsiia vnutrishnikh audytiv systemy upravlinnia yakistiu pidpryiemstva z vyrobnytstva likarskykh zasobiv. Kharkiv: NTMT, 28.

7. Syrovab, H. O., Lebedynets, V. O., Makarov, V. O., Zavada, O. O. (2018). Osoblyvosti provedennia vnutrishnikh audytivu kliniko-diahnostychnykh laboratoriiakh. Proceedings of articles the international scientific conference., Karlovy Vary Kyiv, 1447-1451.

8. Sun, J., Zhang, Y., Zuo, Z., Chang, Z., Guo, J. (2017). Research on the Effectiveness Improvement Strategy of Quality Management System of Chemical Enterprises. Chemical Engineering Transactions, 62, 1603-1608.

9. Krishtopa, B. P., Gorachuk, V. V. (2014). Organizaciia vnutrennego audita v sisteme kontrolia kachestva medicinskoi pomoschi. Seriia Medicina. Farmaciia, 4 (25 (175)), 163-168.

10. Hetalo, O. V., Yavdoshchak, P. T. (2019). Osnovni etapy planuvannia ta provedennia samo inspektsii (vnutrishnoho audytu) u farmatsevtychnii haluzi. $\Lambda$ 'OHO $\Sigma$. Mystetstvo naukovoi dumky, 2, 65-66.

11. Lebedynets, V. O., Kovalenko, S. M. (2012). Orhanizatsiia vnutrishnikh ryzyk-oriientovanykh audytiv farmatsevtychnoi systemy yakosti. Upravlinnia, ekonomika ta zabezpechennia yakosti v farmatsii, 2 (22), 21-26.

12. Ubohov, S. H., Trokhymchuk, V. V., Todorova, V. I., Zahoriy, V. A. (2019). Process model of the pharmaceutical integrated management system modelowanie procesów farmaceutycznego zintegrowanego systemu zarządzania. Wiadomości Lekarskie, 72 (2), 201-208.

13. Bekčić, S., Kelečević, N., Marinković, V., Tasić, L., Krajnović, D. (2015). Developing a quality management tool for preparing Good Distribution Practice audit of pharmaceutical contract vaccine distributor. Indian Journal of Pharmaceutical Education and Research, 49 (3), 174-182. doi: http://doi.org/10.5530/ijper.49.3.2 299-302.

14. Funikova, O. V. (2015). Pidstavy klasyfikatsii zapytan u teorii kryminalistyky. Porivnialno-analitychne pravo, 5,

15. ISO 19011:2018 Guidelines for auditing management systems (2018). ISO/FDIS 19011:2018 Supporting technologies. terminology.

16. ISO 9000:2015 Quality management systems - Fundamentals and vocabulary (2015). ISO/TC 176/SC 1 Concepts and

Received date 08.11.2019

Accepted date 27.11.2019

Published date 30.12.2019

Tetiana Karamavrova, Postgraduate Student, Department of Quality Management, National University of Pharmacy, Pushkinska str., 53, Kharkiv, Ukraine, 61002

E-mail: karamavrova.qms@gmail.com

Viacheslav Lebedynets, Doctor of Pharmaceutical Sciences, Professor, Head of Department, Department of Quality Management, National University of Pharmacy, Pushkinska str., 53, Kharkiv, Ukraine, 61002

E-mail: quality@nuph.edu.ua 